\title{
Parenting Blogs and Children's Online Privacy On the Privacy Management of Parent Blogs in Turkey
}

\author{
Oya Morva \\ istanbul University Faculty of Communication \\ https://orcid.org/0000-0003-3788-9053 \\ oyamorva@istanbul.edu.tr
}

\author{
Derya Gül Ünlü \\ istanbul University Faculty of Communication \\ https://orcid.org/0000-0003-3936-7988 \\ derya.gul@istanbul.edu.tr
}

\begin{abstract}
This study aims to determine how the digital privacy of the child is addressed based on the content shared by parents on the parent blogs in Turkey. Today, parents share content about their daily parenting practices and the development of their children on digital communication media. The fact that the majority of the content shared is about the child makes it a necessity to think about the digital privacy of the child. In this context, parenting blogs are important in that they are digital texts through which mothers and fathers convey their relationship with their children and their parenting roles to the readers in the form of an autobiography. Within this study the Turkish parent bloggers' opinion on their privacy management of the content that they share was analyzed using a qualitative research design. The data collection phase was constructed based on face-to-face semi-structured interviews with 15 purposively selected parent bloggers and qualitative content analysis was used as the data analysis method. Regarding the privacy management of the blogger parents, four basic determinants have been detected: (1) ethical principles and auto-control, (2) the child's intervention and demands, (3) interactions with their followers and (4) the legal context.
\end{abstract}

Key Words: Parenting blogs, privacy, online privacy, sharenting, children's online privacy.

Received: 30.03.2021 • Accepted: 27.09.2021

http://ilefdergisi.ankara.edu.tr

ilef dergisi : $\odot 2022$ : 9(1) - bahar/spring: 9-29

Research Article DOI: 10.24955/ilef.1073284 


\section{Ebeveynlik Blogları}

ve Çocuğun Çevrimiçi

\section{Mahremiyeti}

Türkiye'deki Ebeveynlik Bloglarının

Mahremivet Yönetimi Üzerine

Oya Morva

İstanbul Üniversitesi Illetișim Fakültesi

https://orcid.org/0000-0003-3788-9053

oyamorva@istanbul.edu.tr
Derya Gül Ünlü

İstanbul Üniversitesi Illetișim Fakültesi

https://orcid.org/0000-0003-3936-7988

derva.gul@istanbul.edu.tr

Öz

Bu çalıșma, ebeveynlerin dijital ortamdaki paylașımları üzerinden çocuğun dijital mahremiyetinin nasıl ele alındığının belirlenmesini hedeflemektedir. Günümüzde ebeveynler, günlük ebeveynlik pratikleri ve çocuklarının gelișim süreçlerine ilișkin içerikleri dijital iletișim ortamlarında paylașmaktadır. Paylașılan dijital içeriğin önemli bir kısmının çocuğa dair olușu ise, çocuğun dijital mahremiyeti üzerine düșünülmesini gerekli kılmaktadır. Bu çerçevede ebeveynlik blogları, anne ve babaların çocuklarıyla olan ilișkilerini ve ebeveynlik rollerini okuyucularına otobiyografik bir biçimde aktardıkları dijital metinler olmaları bakımından önem tașır. Bu çalıșma kapsamında, Türkiye'deki ebeveynlik blogu sahibi yazarların paylaștıkları içeriğin mahremiyet yönetimine ilișkin görüșleri, nitel bir araștırma tasarımı üzerinden analiz edilmiștir. Amaçı örneklem seçimi ile belirlenen 15 blog yazarı ile yüz yüze yarı yapılandırımıș görüșme gerçekleștirilmiș ve veri analizi yöntemi olarak nitel içerik analizi kullanılmıștır. Sonuç olarak, blog yazarı ebeveynlerin mahremiyet yönetimi ile ilgili olarak dört temel belirleyen tespit edilmiștir: (1) etik ilkeler ve otokontrol, (2) çocuğun müdahalesi ve talepleri, (3) takipçilerle etkileșimleri ve (4) yasal bağlam.

Anahtar Kelimeler: Ebeveynlik blogları, mahremiyet, çevrimiçi mahremiyet, sharenting, çocuğun çevrimiçi mahremiyeti.

Makale Geliș Tarihi: 30.03.2021 • Kabul Tarihi: 27.09.2021

http://ilefdergisi.ankara.edu.tr

ilef dergisi - (c) 2022 - 9(1) - bahar/spring: 9-29

Araștırma Makalesi DOI: 10.24955/ilef.1073284 
It is not possible to speak of a single accepted definition of the concept of the privacy since its definition depends on the culture, society, time etc. As Solove $(2008,1)$ states, "currently privacy is a sweeping concept encompassing (among other things) freedom of thought, control over one's body, solitude in one's home, control over personal information, freedom from surveillance, protection of one's reputation from searches and interrogations." Although the history of the concept can be dated to much earlier, it was Samuel Warren and Louis Brandeis who first recognized the threats to privacy caused by technological and societal developments (Lukacs 2016). In their famous article 'The Right to Privacy' (1890), they demand the recognition of the right to privacy as letting them be alone. The framework of the concept was expanded by 1905 as one's control over information about oneself. It is worth mentioning that what made Warren and Brendais realize this is the emergence of tabloid newspapers that provided a fertile field for photojournalism and gossip.

The current digital media environment has gone far beyond information sharing. It "has become a place where individuals can express ideas, opinions, build a public image or just interact with other people, either by sharing information and knowledge or by participating in cultural, social and/or political activities" (Sartor \& Viola 2010). In other words, it enables a wide variety of 
information to be shared and spread more easily than in any other period in history. This is so much so that according to some, it has become possible to characterize the current culture with the concept of "oversharing" which has a negative connotation (Agger, 2012; Brabazon 2016). The information sharing possibilities and the potential of the digital environment has made it inevitable subject of discussion in the field of social sciences in relation to the concept of privacy (Solove 2011; Cannataci \& Friends 2016; Mcnish 2016).

When it comes to sharing information about children, information control and privacy become even more complicated in the digital media age (Blum-Ross \& Livingstone 2017; Livingstone \& Byrne 2018; Siibak \& Traks 2019). Considering the popularity of photo and story sharing about children, it becomes inevitable to consider parental sharing practices through a series of questions: Who (parent or child) owns the information shared on digital platforms? How active is the child in deciding what information to share? Are the children emotionally or physically harmed by 'sharenting' practices? Where does the parent's freedom to share end and the child's privacy begin? How should this sharing of information about the child be handled as an ethical issue? What are the legal regulations on this subject and are they sufficient? There is a notable body of literature from various disciplines that problematizes online privacy concerning similar questions and it is continuing to expand (Haley 2020; Kline 2020; Schmidt 2011; Steinberg 2016). This study is also derived from such an interest and it aims to explain the privacy management of parent bloggers in Turkey. In addition, when the relevant literature is examined, it is seen that there is no study focusing on the online privacy management of parenting blog writers in Turkey, and it is thought that the research will fill this gap.

\section{Sharenting and Its Problems}

Sharenting describes the ways that many parents share information about their parenting practices and their children's lives in the digital environment (Collins Dictionary and Macmillan Dictionary). It can be suggested that social media also provides several functions to mothers and fathers regarding their parenting role. By getting in touch with their family, friends or other parents through social media, individuals can strengthen these relationships and have the social capital that they need (Jang \& Dworkin 2014; Young 2011). It can also be suggested that parents have experience of showing their care and support for their children through the content that they share on social media about their children (İnan-Kaya \& Kaya 2018), thereby constructing the par- 
ent identity they aim for (Blum-Ross \& Livingstone 2017). On the other hand, there are also positive aspects to the individuals' sharing posts about their parenting practices on social media such as receiving social and psychological support through 'likes' and comments on the posts, getting information from more experienced parents who went through similar situations and relieving the feeling of loneliness (Keith \& Steinberg 2017, 413-414). In this regard, it can be argued that parents use social media channels for purposes such as sharing content about their children, following the posts of other parents, exchanging information and having access to an environment of solidarity for the various social and psychological problems they encounter (see Bartholomew et al. 2012; Lupton 2016; Lupton \& Pedersen 2016; Walker et al. 2011).

As Steinberg states $(2017,847)$, although most parents act with good intentions when they share about their children, they often share without being fully informed of the consequences of their online disclosure. They may reveal personal information about their children to other people, online services, data brokers or surveillance authorities which may cause safety risks (Minkus et al. 2015). These online disclosures have the potential to benefit children in many ways. However, considering the child's right to privacy means that there may be legal risks as well (Steinberg 2017).

Studies show that parental disclosure on social media may cause (1) digital kidnapping, (2) for some children to be bullied by other children as a result of embarrassing pictures shared by their parents, (3) the risk of the child becoming an open target for strangers by explicitly announcing the places where the child is regularly located through spatial social media applications and venue tags and (4) the social and psychological life of the child may be negatively affected when he/she reaches adulthood due to the information shared (Siibak \& Traks 2019).

\section{Parenting Blogs/Microblogs and Privacy Management}

Although there are many definitions for blogs (Boyd 2006), in general, blogs are social media websites typically used to share thoughts, opinions, reports, user-created content and links to content found on other websites (Blood, 2002). They are a popular form of easy-to-use personal publishing, there are over 600 million blogs in the world as in 2022 (Byers 2022). Among these, as the statistics above point out, parenting blogs are very popular. Thus we can say that parents are very enthusiastic adopters of blogging and microblogging practices (Dugan et al. 2015). 
Parenting blogs and blogger parents share contents including their personal experiences with their followers. In this regard, parenting blogs, unlike other types of blogs, can be defined as digital settings in which individuals give advice to other parents by autobiographically conveying their opinions on their children's lives and motherhood/fatherhood experiences (Lupton 2016; Morris 2014). Given that blogs provide "strong notions about the author's personality, perspective, and desires" (Nardi et al. 2004, 42), blog contents can be defined as digital texts that convey the adopted parenting understanding and model to the reader. Furthermore, blogs allow their readers to reinterpret these parenthood insights in the context of their idioms and cultural origins, in addition to providing parenting models through their authors' own experiences (Powell 2010). Therefore, parenting blogs are important because they are cultural spaces that represent the author's view of parenting while also allowing the reader to reinterpret various parenting approaches by observing them. The cultural aspect of parenting blogs makes it necessary to examine the studies on parenting blogs in Turkey. Few research (Aktan \& Kayış 2018; Gürçayır-Teke 2014; Morva \& Gül-Ünlü 2021; Sayımer \& Derman 2019) focusing on parenting blog posts have been conducted in Turkey in this regard. When these studies are examined, it is seen that parents in Turkey produce blog content to keep track of and remember memories of their child, to share experiences and exchange information between parents, to inform their readers in line with their personal understanding of parenting, to raise awareness, to negotiate the role of parenting and gender norms, to benefit from the experiences of the readers, and to get social support from parents with similar problems.

According to Schmidt, blogs/microblogs, contribute to the emergence of "personal public spheres" which are one of the defining features of the social web (Schmidt 2011). Blogging is a hybrid between the modes of publishing and engaging in conversation, especially in the case of seemingly paradox online journals which are both personal and public at the same time. According to Schmidt (2011), this new type of public sphere blurs the boundaries between the personal and the public. Due to this feature, the social web has been the subject of various studies in the literature, especially relating to the protection of personal data and security concerns (Gross \& Acquisti 2006; McCullagh 2008; Krasnova \& Friends 2008; Fogel \& Nehmad 2009; Child et al. 2011; Mamonov \& Benbunan-Fich 2018).

This feature of the social web has made it necessary to renew privacy management concerning the digital environment. Considering blogging prac- 
tices specifically in their work, Child and Petronio (2011) stated that we should begin to understand the way that privacy management functions within a larger communicative system. Child et al. (2011) showed that bloggers essentially scrubbed their blog site and adapted their typical privacy rules to the new ones that better protected them from the online community regarding that particular form of blogged information. Similarly, Schmidt (2011) argues that blogging/microblogging practices, rather than simply eroding privacy and fostering digital exhibitionism, reconfigure the context for the purpose of identity management in a more complex way. As Schmidt (2011) explains, "with regard to blogs/microblogs managing privacy refers to the ways people actively use the technology to selectively disclose certain personal information to certain audiences (and also not disclose certain information to others)." In other words, individual bloggers select and present content online that is framed by technology or code, but also by rules and relations. Along these structural dimensions, we can identify groups or communities of blogging practices. The analytical model of Schmidt, which accounts both for the social structuredness of blogging and its dynamic nature, can also serve as a framework to look at the development of the blog/microblog-based practice of privacy management (Schmidt 2007; 2014). In other words, it can be said that privacy management in the social web is not only abandoned to the mercy of technology or the code itself in a deterministic way. It has created a new set of rules that derive from the relationship among user groups.

\section{Research Method}

Within this study, the Turkish parent bloggers' opinion on their privacy management of the content that they share was analyzed using a qualitative research design. Semi-structured interviews were used as the data collection method and qualitative content analysis with a directed approach (Hsieh \& Shannon 2005) was used as the data analysis method. Our research's systematic framework consists of 4 phases: (1) data collection, (2) data preparation, (3) qualitative content analysis and (4) the interpretation of the results. The data collection and data preparation phases were constructed based on faceto-face semi-structured interviews with 15 purposively selected (7 women and 8 men) parent bloggers. Interviews were conducted between September 2020 and January 2021. All the blogs are owned by Turkish parents, and they all posting in Turkish. The children of all the interviewed bloggers were under 18 years old (the oldest was 14 years old) but the age and gender differences of the children of the bloggers did not determine the choice of interviewees. 
All the interviewed bloggers have been producing parenting content for a long time (minimum 2 years, maximum 14 years). This made it possible to see how both the interaction with the followers and the intervention of the growing child in the content were effective on the privacy control in the process. An interview guide was developed to answer the research questions and to focus on certain topics during the interviews. Using existing theory and prior research a deductive category application (Mayring 2000) was used and within the scope of the focus of the study, the research questions were grouped based on 3 predetermined categories: (1) awareness of the ownership of the information shared, (2) awareness of the risks and measures taken and (3) the determinants of the content of the parent posts. The content analysis phase was built on the framework method and analysis was carried out using the predetermined categories (see Hsieh \& Shannon 2005). Finally, the focus of the interpretation of the results phase is to measure the data quality and interpret the findings regarding the privacy management of the blogger parents.

\section{Findings}

\section{Whose Information is Shared on the Parent Blogs?}

All the bloggers interviewed agreed that the content on their blog conveys their parenting experiences. Bloggers think that what is reflected from the blog content is primarily their own parent identity. However, in answer to the detailed questions about the content itself, the parents also state that they also share information about someone else, their child:

Since the blog is mine, I don't think much about it (r.n. talking about whose information shared), but I am careful not to put any content that offends my kid. I mean, sometimes she drives me crazy, my daughter is a very difficult child, she forced me a lot and now I accept she is a difficult child. But I wrote about the subjects that were challenging for me, not about her. And of course, because it's a personal diary, I felt like gossiping about her from time to time (C.S).

As it is understood, one of the parties involved in parenting is the child. The focus of sharing is based on the dynamic relationship between the child and the parent. One blogger described the double-sided and dynamic relationship that creates the content as follows:

Parenting was much more difficult before, when it was new, though now there are different challenges. Much more material was coming out to write on then. One reason for this was that my relationship with my child until the age of four or five was a little more critical parent vs. rebellious child kind. A lot of material to write on was coming out of it. Not very positive energy, but was producing 
something readable. After that age, I moved to a little more adult, he positioned himself a little more an ordinary child. There is also great entertainment derives from this relationship with my child but not that much material to write on. What has changed? I started to have a little bit of difficulty in finding the contents. Nowadays I started to focus on spending my time with my son, so maybe there is stuff to write on however I'm not looking. Because the child is at school. The time he spends father and mother is running short. Also since you are no longer a newbie in childcare, you focus on different things now (S.Ö).

Based on the above, it can be said that the interviewed bloggers are aware that the parenting content is related not only to the parent but also to the child. This awareness is revealed in the two different attitudes present in their blog posts: (1) keeping secret as much information about the child (face, name, birthday etc) on the blog as possible and making only the blogger's parental identity visible.

Frankly I do not use photos of my children. More precisely, I do but I cover their faces. Because although my blog is not a blog that can be misunderstood, my children may not want me to share them. My child can say I wish you didn't write about me. So, he/she can stay a little more anonymous if his face is not visible. However, I have a couple of photos my own, they have my face open (C.S).

(2) Sharing information about the child more openly and make the digital selves of both the child and parent visible.

I am highly appreciated in social circles for being a good father. This doesn't bother me. That's me after all. After a certain point, I started to be known not as O.; but as Z.'s father. For those who don't know my name, I'm Z's father. Or while I was meeting someone I was Z's father. Spectacular! By the way, there are still people on the street who knows me as Z's father (O.P).

In both cases, the posts are passed through certain filters - detailed in the following sections - by bloggers regarding privacy and data security.

Nevertheless, when the details of the shared content were discussed, it was revealed that detailed personal information about the child was available in all but three blogs. The information we are talking about is, of course, not presented with clarity as it is in the form of an identity card but it can be filtered out from the text and photographs shared in a detailed review:

Of course I don't share open and detailed data as much as possible. The blog doesn't contain venue information or birthday and school information about my 
daughters. I usually don't put these on the blog. But yes, those who follow constantly can trace where we are. Because we go to the ballet, for example, we share from there. But yes, I do not put it as a way to emphasize it (Ö.H).

For example, the topic of school choice, one of the most popular topics in blogs, can make the school that the child goes to known to their followers. Blog posts in certain venues related to the activities that the child regularly performs (sports, art, science etc.) make it possible to easily identify the places where the child is regularly. Bloggers are aware that their followers and anyone else who reads their blog posts chronologically may be able to gain access to a substantial amount of the child's personal information, just like putting together the pieces of a puzzle:

Whoever follows me very carefully can find anything. Because I share about myself. I'm also tagging on Foursquare. If someone who knows what school's swimming team my kid in is can easily find out what time she is there. Anyone can get the answer (Ö.P).

Moreover, when the interviewees were asked what personal data they share about their children on the blogs, except for 4 bloggers, all of them said that the photographs and the child's name and surname were shared (or easily found). This enables their child to be easily identified. There were bloggers who stated that they had followers in the public sphere who recognized them and had come up to them to talk:

There were times when I meet people out there who knew from me from the blog, and there were times when I was terrified. One day, while I was with my motherin-law, they came running over us. Another time, when I was alone, someone came from behind, hugged, and scared me! (B.A).

\section{What Concerns Determine the Content of the Parenting Posts?}

Based on the interviews conducted, it is possible to say that the information sharing about the child is generally shaped by four concerns: (1) ethical principles and self-control, (2) the child's intervention and demands, (3) interactions with their followers and (4) legal context.

Ethics, which explain what is right and wrong in a moral sense, appear to be the most determining factor in the sharing of the parent bloggers. A personal ethical attitude towards shared content as a kind of self-control system where bloggers negotiate their posts by putting themselves in their children's shoes has been observed in all bloggers interviewed: 
Once, my daughter had all the laundry in her room messed up. I shared the post because it was a funny moment for me. I shared it, then the interaction started coming and it increased. Then I realized that. Wait a minute! I said to myself, do I mess around my clothes and share a photo of it? And there was a moment when I was so sad (AA).

In some cases, this ethical attitude may itself be caused by the society lived in rather than only the individual sourced. One of the interviewees expressed not sharing photographs of her children by associating it with the cultural codes of the society that she lived in:

I am not sharing my kids' photos on the blog. So it is also the same in the culture I live in. Photos of children are not shared on many web pages. There are no web pages of kindergardens here, in this country. It feels right to me and that's why I limit it by covering the child's face (C.S).

This attitude can also be considered as the reason for the bloggers' practice of the management of the impressions about children on their blogs:

You are already saying something about the child. Her/his friend reads it, and someone else also reads it. Here you want to put something, but there is an impression that the child wants to create about himself/ herself. So I try to make sure there is nothing to spoil that impression in my posts (M.Ö).

This example highlights the issue of how the child is represented by the parents on the blog which also emerges as an issue that parents (especially the fathers) ponder over.

Another factor that the parents take into account when sharing content about the child is the child's opinion or feelings about the act of sharing itself. The parents interviewed state that they respect their children's decisions regarding sharing. All the parents interviewed, aware that the information shared is also about the child, stated that they would remove the content if their children objected. However, it should be emphasized that the age of the child is decisive in this. The bloggers stated that in general, children start expressing their opinions on the blog posts after they have learned to read. It has also been stated that they are more involved in the content during their adolescent years:

As of today, since A. learned how to read and write, I no longer share anything that he does not approve of. I was not posting anything that I thought would bother him anyway. But since he began to read and understand, if I am going to put something, I make sure to have his approval (M.Ö). 
One of the interviewees, Ö.P, stated that although it did not match his motivation to keep a blog (archiving and recording), he allowed his daughter to intervene in terms of the content:

Now there are some contents that my daughter doesn't want me to share. Because Z. started to pay attention to whether she looked beautiful in the photo. How is the look, how is the pose? She is paying attention now. She and her friends all have a mobile phone. And there is a problem that her friends also follow me. I find the thing very valuable... that something published should not be easily removed. I do not delete the photos I took either. I archive them. Some photos can be out of focus but I transfer and backup all photos in the same way. There are of course those that I choose and use, but I don't like to delete the rest because I look bad. However, this manner has changed in the last 2 years. When I post without notifying Z., she deletes the post (Ö.P).

Therefore, it can be said that the sharing rituals of the parents transform over time as their children reach an old enough age to interfere with the content.

However, it should be added that this transformation of the content over time is not only due to the intervention of the child but also the parental selfcontrol. So much so that Ö.P, one of the interviewees, stated that as a parent blogger, he had to write about the attitude changes as part of his daughter's adolescence. He got to a point where he could not do so, so he stopped writing:

When I first started blogging, I also visited a lot of blogs. Foreign fatherhood blogs. The year was 2006. I found a lot of blogs that already ended. At a certain point, the blogger had said that 'he would not write anymore, because his daughter learned to read. And the things that I will write from now on will concern the child's private life. Then I wondered if I would be like this one day. It happened. This is one of the reasons why I am not writing today. Because what will I say when I write something about adolescence? Yesterday Z. slammed the door, bellowed out something, and left. Of course, I will not write this, but I have to... (Ö.P).

In other words, the advancement of the age of the child brings with it more problems concerning the privacy issue of the child related to the parental posts.

In the blog posts, the interaction of the followers or readers can also determine the content. As in the example below, the interaction with the post can cause the bloggers to change their attitude about sharing it: 
I had problems with the followers, unfortunately, I even started censoring the contents for this reason (...) In the very early days of my blog, I shared a photo shows that my kid taking a bath with his father, my kid's face was covered in the photo. They were in the bathroom with my husband. Nothing is visible, but the father and daughter were in the bathroom. This caused a lot of reaction. At that time, there was a sudden issue as to whether girls can take a bath with their fathers. I wondered if it was due to this photo. But it was nice because then people discussed this issue, I don't think that photo still exists, but I haven't posted such a photo after that. So I learned (C.S).

Although the legal context is the category least questioned and voiced by the parents regarding their blog posts, it affects the content to a certain extent. Three of the bloggers interviewed tried to explain their sharing preferences using legal concepts such as abuse, rights, law and crime:

When I'm sharing a photo, I looked at these: 1) If I share this photo, will it take me to court in the future? Am I violating my kids' rights is the question. 2) Am I abusing by sharing? 3) What happens if I share this without his/her permission? (A.A).

One of the bloggers, L.Ö, pointed out how the legal context shapes the content by saying:

I am aware of children's rights. Both, I am aware of these rights in the legal context and also I care about their existence. When I think about it, there is a fact that when we were a child, our photos were visible to other people only when someone came to our home. They weren't public then but they are now. So I think this is the reality today. I don't put anything they would offend anyway.

To summarize, the ethical dimension of the content shared about the child is the most problematic dimension concerning privacy. The interaction with the child and their followers also affects the bloggers' sharing practices about what or how much content should be shared. Lastly, although the legal dimension related to the privacy of the child in the parent blogs is not as widespread and effective as the ones listed above, it still affects the content of the blog posts.

\section{How Aware They Are of the Risks of Sharenting and What Measures Are Taken by the Parent Bloggers?}

We can see that each of the parents we interviewed are aware of the various risks of the Internet environment and that they use a variety of relatively high or low safety barriers to prevent their children from being harmed concern- 
ing their posts. Being selective in the shared photos of the child is one of the most mentioned and used safety barriers: "There are posts where we share children's faces. Of course, we share them within certain limits. Their privacy is important. I mean... Even sharing children themselves is a part of their privacy though..." (Ö.H). Regarding the content that is particularly avoided in the photographs, all parents, without exception, stated that they take care to ensure that their children are dressed. However, the limits on being dressed may also vary from parent to parent. For example, a blogger can share photos in bathing suits, although he says he cares for his child to be dressed:

If there are content where I post images of my son, I make sure that the photographs or videos are mostly dressed, but I do not bother too much. I also share a photo of him in a bathing suit in summer, so I am not that picky I mean... But I do not want to go into details in images or articles that reveal the details of my private life too much (S.Ö).

Another one may appear to have drawn the boundaries on this issue more clearly:

At the beginning, I was sharing very fearlessly and very comfortably. I was sharing not only on my blog but also on a photo-sharing website, Flickr. I was not just sharing them, I was backing up my photos there. And it was public. Then one day I noticed the thing and my blood froze. There are also some people among the followers... I don't know if it is pedophilia, but... I noticed the number of followers started to increase. Comments were coming. Especially under some of the photos, I call beach photos. or more nude photos Then I closed it to the public anyway. So I made it only available to followers. I even remember removing some photos. Therefore, I have always paid close attention to this. Yes, but you know, have I prevented myself in a very obsessive way? I haven't prevented it. You know there is an attitude on the net. Let me put an emoji on my child's face. I've never done that. But of course, the internet was a much more innocent environment in the beginning.

It can be understood that negative interactions with their followers over time is a factor in the choice of which photo of the child to share.

The parents state that they can choose not to share images of their children in private areas such as bathrooms, toilets or rooms. But if they do share private areas, they reflect on and choose the photo carefully. For example, only one mother among the parents interviewed stated that she shared one of the images of her child in the bathroom: "It was a post about toilet training. I 
remember that I uploaded a part of the toilet seat and a photo of D.'s face only. Nothing else could be seen" (B.A). Even though the photos of the children in their bedrooms and sleep have been shared more commonly, it is observed that the selection of the photograph is very meticulous.

There are a couple of photos while my child sleeping, but I control myself at the maximum level while choosing the photo. There is no nude photo, I don't put nude photos. I don't remember if there is a photograph of a bath when he was a baby, but there are some shows of his swimming. But I am trying to be meticulous about that. There are cases of pedophilia or something, that is always in the back of our minds (M.Ö).

To gain a more detailed insight into the parents' level of knowledge about privacy and security, the bloggers were also asked whether they took any security measures concerning their children's social media accounts. It has been observed that they are keeping all of their child's social media accounts under detailed control. The majority of them pass on first-hand information to their children about how to use their account: "I am telling him things such as 'use this one instead of this, there is an anti-virus'. Recently I advise him as 'son if something is free on the internet, you know it is not actually free' (H.Ö). Again, who the followers are and how they interact is monitored by the parents:

My daughter's followers and what she follows are routinely checked by her mom and me. The account is regularly reviewed by us. Who is this? Do you know this? Why is this following you? Why are you following this? Her mother or I are in control. She is explaining routinely as 'I know this one from here and from there'. When someone she does not know sends a follow-up request, she either refuses or asks if he/she is our friend (Ö.P).

It is also possible to say that they are very controlling about the content that their children watch and they are aware that it is possible to associate with the harmful content. Beyond that, it is possible to say that the interviewees are also aware of the concepts of big data and digital surveillance:

So look, security is an illusion. You are not safe right now. If you are using this (pointing phone) you are not safe. It's done. You have two possibilities, you will never enter to Internet world or accept it as it is. All my profiles on the internet, everything is open. Because I'm looking at the content I write. Looking at whether what I'm writing could pose a threat. You must be the filter itself! (H.Ö).

As a result, it can be said that blogger parents came out as a homogeneous group that is well-equipped with digital literacy. Although they are not 
directly educated in digital technology or do not do business related to digital media as a profession, it has been observed that there are people they receive such a consultancy from first hand (such as their spouse or a sibling).

\section{Conclusion}

According to Blum-Ross and Livingstone (2017, 4), parent bloggers exhibit experience with the dilemmas that many parents face as social media users regarding their posts: "to represent one's own identity as a parent means making public aspects of a potentially vulnerable child's privacy and yet because they are parent they are precisely the person primarily responsible for protecting that child's privacy." Moreover, the research findings show that this determination is correct for our sample as well. Even though they underline the emphasis on parenting in the content streaming from the blog, the blogger parents are aware that they share information about their children as one of the main parties in the parent-child relationship.

This dilemma is largely due to the structural features of the blogosphere. Being a blogger requires presenting yourself authentically, meeting the professional standards of the blogging community and maximizing your audience (Blum-Ross \& Livingstone 2017). The flow that these structural features interact with makes it unique and enables each blogger to produce what we call blog content. Therefore while sharing as a blogger whose theme is parenthood in general, it is often inevitable for them to share data about their child while creating content. However, as the research results show, there are different personal forms of sharing about the child. It is possible to protect the privacy of the child at a certain level with various forms of sharing. The security barriers are determined on a personal level. While saying this, it is taken into account that although there is always a potential risk, the study did not find an example in the sample group where the child was directly physically or psychologically harmed by the parents' sharing practices.

Four basic determinants have been determined in the blog posts: (1) ethical principles and auto-control, (2) the child's intervention and demands, (3) interactions with their followers and (4) the legal context. Ethical principles and self-control appear to be the most used and important determinants in terms of the content. The fact that the spouses frequently consult each other regarding the content of the posts appears to be self-control. The second and third determinants point to the interaction with the second (child) and third (follower) persons in accordance with the structural features of the online environment. Although it is important to get the opinion of the child about 
sharing in general, it is not possible to get the consent of the child until they reach a certain age. In other words, the age of the owned children appears to be a factor in obtaining approval for the content. In general, it has been observed that after the children learn how to read and write and become aware of social media, the blogger parents consult their children about their posts. All bloggers have stated that they have taken a stance in favor of removing or not sharing the content that their children does not want them to share. They agree that they won't keep content on their blog that their kids don't like to see about themselves.

It has been observed that especially negative or potentially risky responses in their interactions with their followers enables the bloggers to handle their blog content concerning privacy. The legal context is the least considered context when sharing content. Based on the sample of the research, it has been observed that privacy is treated as a cultural conceptualization and as a set of practices rather than pointing to a legal context. One reason for this may be that in Turkey like the rest of the world, it is not yet possible to talk about a comprehensive law or a legal practice that has been agreed on by internet law.

Another conclusion of the research findings is that the digital literacy of parent bloggers in Turkey is at quite a high level. Bloggers use their knowledge on this subject in the security and privacy management of their blogs, as well as when controlling their children's use of social media, such as conveying information about the potential risks to the child.

It should also be noted that the sample of this research consisted of a highly representative but very limited parent group due to the nature of the qualitative research. Moreover, the findings of the research reveal that the group in question is at a very high level in digital literacy. However, although not specific to this group, sharenting practices on various digital platforms have the potential to violate children's privacy and expose them to various risks. Therefore, this issue is too important to be left to the existence of various mechanisms applied at the individual level. For this reason, it is important to underline that there is a need for macro-level regulations, such as the development of social policies that increase awareness and knowledge about child privacy, as well as legal sanctions.

\section{Funding}

This study was conducted with the support of Raoul Wallenberg Institute Turkey Human Rights Capacity Building Program. 


\section{References}

Agger, Ben. 2012. "Oversharing: Presentation of Self in the Internet Age". New York \& London: Routledge.

Aktan, Ercan and Kayış, Hasan Hüseyin. 2018. “Sosyal Medya ve Değişim: Bloglar Aracılığıyla Anneliğin Evrimi Üzerine Netnografik Bir Analiz”. AJIT-e Bilişim Teknolojileri Online Dergisi 9(32): 39-54.

Bartholomew, Mitchell, Schoppe-Sullivan, Sarah, Glassman, Micheal, Dusch, Kamp Claire (2012). "New Parents' Facebook Use at the Transition to Parenthood". Family Relations 61(3): 455-469. doi: 10.1111/j.1741-3729.2012.00708.x

Blum-Ross, Alicia and Livingstone, Sonia. 2017. “Sharenting”: Parent Blogging, and the Boundaries of Digital Self". Popular Communication 15(2): 110-125. doi: $10.1080 / 15405702.2016 .1223300$

Blood, Rebecca. 2012. "The Weblog Handbook: Practical Advice on Creating and Maintaining Your Blog". Cambridge, MA: Perseus Publishing.

Brabazon, Tara. (2016). "Digital Dieting: From Information Obesity to Intellectual Fitness". New York: Routledge.

Boyd, Dannah. 2006. "A Blogger's Blog: Exploring the Definition of a Medium". Reconstruction 6(4): 1-21.

Byers, Kyle. 2022, 2 January. "How Many Blogs Are There? (and 141 Other Blogging Stats)". GrowthBadger, Retrieved from https:// cutt.ly/DhDa61s

Cannataci, Joseph A., Zhao, Bo, Vives, Gemma Torres, Monteleone, Shara, Bonnici, Jeanne Mifsud and Moyekine, Evgeni. 2016. "Privacy, Free Expression and Transparency: Redifining Their New Boundaries in the Digital Age". Paris: UNESCO Publishing.

Child, Jeffrey T. and Petronio, Sandra. 2011. “Unpacking the Paradoxes of Privacy in CMC Relationships: The Challenges of Blogging and Relational Communication on the Internet. In: K.B. Wright and L.M. Webb (ed.) Computer-Mediated Communication in Personal Relationships, 21-40. New York: Peter Lang.

Child, Jeffrey, Petronio, Sandra, Agyeman-Budu, Esther and Westermann, David A. 2011. “Blog Scrubbing: Exploring Triggers that Change Privacy Rules". Computers in Human Behavior 27(5): 2017-2027. doi: 10.1016/j.chb.2011.05.009

Collins Dictionary (n.d.) Sharenting. Retrieved from https:/ / cutt.ly/ZhDaxBT

Duggan, Maeve, Lenhart, Amanda, Lampe, Cliff and Ellison, Nicole B. 2015, 16 July. "Parents and Social Media". Pew Research Center. Retriewed from https:/ / cutt.ly/WhGAYkd

Fogel, Joshua and Nehmad, Elham. 2008. "Internet Social Network Communities: Risk Taking, Trust, and Privacy Concerns". Computers in Human Behavior 25(1): 153-160. doi: 10.1016/j.chb.2008.08.006 
Fox, Alexa K. and Hoy, Mariea Grubbs. 2019. "Smart Devices, Smart Decisions? Implications of Parents' Sharenting for Chilren's Online Privacy: An Investigation of Mothers". Journal of Public Policy \& Marketing 38(4): 414-432. doi: 10.1177/ 0743915619858290

Gross, Ralph and Acquisti, Alessandro. 2005. "Information Revelation and Privacy in Online Social Networks (The Facebook Case)". In: Proceedings of ACM Workshop on Privacy in the Electronic Socety (WPES), 71-80. Alexandris, VA: ACM.

Gürçayır-Teke, Selcan. 2014. “Dönüşen Anneliğe Yönelik Netnografik Bir Analiz: Blogger Anneler". Milli Folklor 26(103): 32-47.

Hsieh, Hsiu-Fang and Shannon Sarah E. 2005. “Three Approaches to Qualitative Content Analysis". Qualitative Health Research 15(9): 1277-1288. doi:10.1177/1049732305276687

İnan-Kaya, Gamze and Kaya, Umut. 2018. “Bir Ebeveyn Pratiği Olarak 'Sharenting'. In: Nejat Akfırat, Donald Staub and Gürkan Yavaş (ed.), Current Debates in Education, 480-549. London \& İstanbul: IJOPEC Publication.

Jang, Juyoung and Dworkin, Jodi. 2014. “Does Social Network Site Use Matter for Mothers? Implications for Bonding and Bridging Capital". Computers in Human Behavior 35, 489495. doi: 10.1016/j.chb.2014.02.049

Keith, Bahareh Ebadifar and Steinberg, Stacey. 2017. "Parental Sharing on the Internet: Child Privacy in the Age of Social Media and the Pediatrician's Role". JAMA Pediatrics 171(5): 413-414. doi: 10.1001/jamapediatrics.2016.5059

Kline, Kip. 2020. “Ecstatic Parenting: The 'Shareveillant' and Archival Subject and The Production of the Self in the Digital Age". Ethics and Education 15(4): 464-475. doi: 10.1080/17449642.2020.1822706

Krasnova, Hanna Günther, Oliver, Spiekermann, Sarah and Koroleva, Ksenia. 2009. "Privacy Concerns and Identity in Online Social Networks". Identity in the Information Society 2, 39-63. doi: $10.1007 /$ s12394-009-0019-1

Livingstone, Sonia and Byrne, Jasmina. 2018. "Parenting in Digital Age: The Challenges of Parental Responsibility in Comparative Perspective". In: Giovanna Mascheroni, Cristina Ponte and Ana Jorge (ed.). Digital Parenting: The Challenges for Families in the Digital Age. 19-30. Göteborg: Nordicom.

Lukacs, Adrienn. 2016. "What is Privacy? The History and Definition of Privacy". University of Szeged Faculty of Law and Political Sciences, 256-265.

Lupton, Deborah. 2016. "The Use and Value of Digital Media for Information about Pregnancy and Early Motherhood: A Focus Group Study". BMC: Pregnancy and Chilbirth 16: 171181. doi: $10.1186 /$ s12884-016-0971-3

Lupton, Deborah \& Pedersen, Sarah. 2016. "An Australian Survey of Women's Use of Pregnancy and Parenting Apps". Women and Birth 4, 368-375. doi: 10.1016/j.wombi.2016.01.008

MacMillan Dictionary (n.d.) Sharenting. Retrieved from https://cutt.ly/1hDaiOR 
Mamonov, Stanislav and Benbunan-Fich, Raquel. 2018. “The Impact of Information Security Threat Awareness on Privacy-Protective Behaviors". Computers in Human Behavior 83, 32-44. doi: $10.1016 /$ j.chb.2018.01.028

Mayring, Philippe. 2000. Qualitative content analysis. Forum Qualitative Sozialforschung / Forum: Qualitative Social Research, 1(2): Art. 20, Retrieved from http://nbn-resolving.de/ urn:nbn:de:0114-fqs0002204

McCullagh, Karen. 2008. "Blogging: Self Presentation and Privacy". Information E Communication Technology Law 17(1): 3-23. doi: 10.1080/13600830801886984

Mcnish, Kevin. 2016. "Goverment Survellience and Why Defining Privacy Matters in a PostSnowden World". Journal of Applied Philosophy 35(2): 417-432. doi: 10.1111/japp.12219

Minkus, Tehila, Liu, Kelvin and Ross, Keith. 2015. “Children Seen But Not Heard: When Parents Compromise Children's Online Privacy". In: WWW 2015-Proceedings of the 24th International Conference on World Wide Web, 776-786. Association for Computing Machinery, Inc. doi: 10.1145/2736277.2741124

Morris, Meredith. 2014. "Social Networking Site Use by Mothers of Young Children". In: Proceedings of the 17th ACM Conference on Computer Supported Cooperative Work \& Social Computing. 1272-1282. New York: ACM Press.

Morva, Oya and Gül-Ünlü, Derya. 2020. "Babalık Da Yaparım Kariyer De! Blogger Babalar ve Erkekliğin Kurucu Rollerinden Babalık Üzerine". Moment Dergi 8(1): 227-245.

Bonnie A., Nardi, Diane J. Schiano, Michelle, Gumbrecht, and Luke Swartz. 2004. “Why We Blog". Communications of the ACM 41-46.

Rebecca Powell. 2010. “Good Mothers, Bad Mothers and Mummy Bloggers: Rhetorical Resistance and Fluid Subjectivities". MP: An Online Feminist Journal 2(5): 37-50.

Sartor, Giovanni and Viola, Mario de Azevedo Cunha. 2010. “The Italian Google-Case: Pivacy, Freedom of Speech and Responsibility of Providers for User Generated Contents". International Journal of Law and Information Technology 18(4): 356-378. doi: 10.1093/ijlit/ eaq010

Sayımer, İdil and Derman, Malgorzata Rabenda. 2019. "Perspectives on Fatherhood and Manhood in New Media: A Narration Analysis of Polish, Turkish and British 'Daddy Blogs'"'. Galatasaray Üniversitesi İletişim Dergisi 31, 111-136.

Schmidt, Jan-Hinrik. 2014. "Twitter and The Rise of Personal Publics". In: K. Weller, A. Bruns, J. Burgess, M. Mahrt and C. Puschmann (ed.), Twitter and Society, 3-14. New York: Peter Lang.

Schmidt, Jan-Hinrik. 2011. "(Micro)Blogs: Practices of Privacy Management”. In. Trepte, Sabine and Reinecke, Leonard. (ed.), Privacy Online, 159-173. Berlin: Springer.

Siibak, Andra and Traks, Keily. 2019. "The Dark Sides of Sharenting". Catalan Journal of Communication and Cultural Studies 11(1): 115-121. doi: 10.1386/cjcs.11.1.115_1

Solove, Daniel J. 2008. “Understanding Privacy”. MA: Harvard University Press. 
Solove, Daniel J. 2015, May 15. “Why Privacy Matters Even If You Have 'Nothing to Hide.' The Chronicle of Higher Education. Retrieved from https://cutt.ly/5hGP6EX

Steinberg, Stacey B. 2016. "Sharenting: Children's Privacy in the Age of Social Media". Emory Law Journal 66, 839-884.

Thierer, Adam D. 2013. "The Pursuit of Privacy in a World There Information Control is Falling". Harvard Journal of Law and Public Policy 36(2): 409-455.

Walker, Susan, Dworkin, Jodi and Connell, Jessica. 2011. "Variation in Parent Use of Information and Communication Technology: Does Quality Matter?". Family \& Consumer Sciences Research 40, 106-119. doi: 10.1111/j.1552-3934.2011.02098.x

Young, Kristy. 2011. "Social Ties, Social Networks, and the Facebook Experience". International Journal of Emerging Technologies and Society 9(1): 20-34. 
